\title{
EDUCAR É SEMPRE UM ATO POLÍTICO: DESAFIOS CONTEMPORÂNEOS
}

DOI: $10.48075 /$ RI.V24I2.25553

Fernanda dos Santos Paulo ${ }^{1}$

Sérgio Trombetta ${ }^{2}$

RESUMO: O pensamento que perpassa o texto é de que não é possível separar educação e política. A reflexão situa-se na contribuição de Paulo Freire para o campo da pedagogia e da filosofia da educação a partir da relação entre Educação e Política, sobretudo em tempos de um projeto de sociedade ultraneoliberal. Abordaremos sobre as teses centrais de Freire em mostrar que a educação é um ato político, e o discurso que se esforça em negar esse status para a educação é um discurso ideológico, pois busca encobrir a realidade através de uma pseudoneutralidade da ação educativa. Freire é incisivo em abordar essa questão; entendemos que a clareza de seu pensamento continua a elucidar essa questão em tempos de globalização excludente e da avalanche de visões neotecnicistas em educação, como ocorre nos dias atuais.

Palavras-chave: Política; Paulo Freire; Educação humanizadora; Educação capitalista.

\section{EDUCATION IS ALWAYS A POLITICAL ACT: CONTEMPORARY CHALLENGES}

ABSTRACT: The thought that runs through the text is that it is not possible to separate education and politics. The reflection is based on Paulo Freire's contribution to the field of pedagogy and philosophy of education based on the relationship between Education and Politics, especially in times of an ultra-liberal society project. We will approach Freire's central theses in showing that education is a political act and the discourse that strives to deny this status for education is an ideological discourse, as it seeks to cover reality through a pseudo-neutrality of educational action. Freire is incisive in addressing this issue; we understand that the clarity of his thinking continues to elucidate this issue in times of exclusive globalization and the avalanche of neo-technicist views in education as it is today.

Key Words: Politics; Paulo Freire; Humanizing education; Capitalist education.

\footnotetext{
${ }^{1}$ Doutora em Educação pela Unisinos. Professora do PPGEd/Unoesc. Militante do Movimento de educação Popular e da Associação de educadores populares de Porto Alegre. E-mail: fernandaeja@yahoo.com.br

${ }^{2}$ Mestre e doutorando em Filosofia. Professor da FACCAT. sergiotrombetta@faccat.br.
} 


\section{A INSEPARABILIDADE ENTRE EDUCAÇÃO E POLÍTICA}

O artigo resulta de uma revisão bibliográfica a partir dos livros de Paulo Freire em diálogo com outros autores.

Freire, desde os seus primeiros escritos, evidenciou a educação como forma de intervenção no mundo. Educação, na perspectiva libertadora, é sinônimo de mudança e transformação das estruturas que atentam contra a dignidade do ser humano. Por isso, é fundamental saber favorável a quem e contra quem desenvolvo meu trabalho cotidiano em sala de aula e, de maneira mais ampla, na sociedade. Nosso trabalho educativo/pedagógico não pode ser um mero passatempo em que reproduzimos os conteúdos, distribuímos notas e aprovamos ou reprovamos os estudantes. O autor exige compromisso ético e político com a transformação das estruturas que desumanizam e negam nossa vocação para o ser mais, para a humanização. Por isso, o ato de educar, necessariamente, implica a dimensão política enquanto espaço de poder e possibilidade de intervenção nas estruturas.

A compreensão dos limites da prática educativa demanda indiscutivelmente a claridade política dos educadores com relação ao seu projeto. Demanda que o educador assuma a politicidade de sua prática. Não basta dizer que a educação é um ato político assim como não basta dizer que o ato político é também educativo. É preciso assumir realmente a politicidade da educação. Não posso reconhecer os limites da prática educativo-política em que me envolvo se não sei, se não estou claro em face de a favor de quem pratico. (FREIRE, 1995, p. 46).

O projeto que perpassa o trabalho de Freire é a libertação dos oprimidos. É plausível dizer que há uma espécie de imperativo categórico no pensamento do autor: a libertação do oprimido e a construção de sociedades alicerçadas na cultura democrática, na justiça social e no respeito radical à agenda dos direitos humanos em sua evolução histórica. Fica evidente em sua proposta de educação que este processo se dá a partir da participação do oprimido, através de um processo incansável de conscientização, pois uma de suas máximas é: a libertação começa na consciência. Educação e conscientização se implicam mutuamente. "Educar, pois, é conscientizar, e conscientizar equivale a buscar essa plenitude da condição humana" (FIORI, 2014. p. 83).

A conscientização torna mais claro os caminhos para a compreensão crítica da situação de opressão e o modo mais eficaz de promover a superação histórica das condições 
de desumanização e de negação da vocação ontológica do ser humano, condições estas que teimam em se impor no intuito ardiloso de forjar como verdade última do ser o ser menos, como caracteriza Freire (1996). Nesse sentido, educar é essencialmente conscientizar, é fazer de cada ser humano um sujeito capaz de lutar contra todas as formas de opressão. Conscientização equivale a politização. "A conscientização já se prefigura como ação transformadora, e não como visão especular do mundo: refazer-se, com autenticidade, implica reconstruir o mundo. A conscientização não é exigência prévia para a luta de libertação, é a própria luta. O retomar da consciência se identifica com a reconquista do mundo: em práxis libertadora" (FIORI, 2014. p. 87, 102). Não existe conscientização fora da práxis.

Para efetivar este projeto de libertação do oprimido é imprescindível lutar contra a realidade histórica marcada pela opressão, a injustiça e a consequente desumanização do oprimido. E isso não se faz sem uma pedagogia crítica, sem uma opção política e sem um projeto de sociedade emancipatório. Nesse sentido, "não pode existir uma prática educativa neutra, descomprometida, apolítica. A diretividade da prática educativa que a faz transbordar sempre em si mesma e a perseguir um certo fim, um sonho, uma utopia, não permite a neutralidade". (FREIRE, 1995, p. 37). Não há fazer humano neutro. Toda educação esconde ou revela uma dimensão política. O político atravessa e constitui o fazer pedagógico, por isso, ele não deve estar ausente no processo de formação dos educadores e nem na prática pedagógica cotidiana.

Na ótica do autor, a educação verdadeira é aquela que assume a tarefa de denúncia das estruturas opressoras e anúncio de horizontes de transformação. Para Freire (1995, 1996, 2000), portanto, a educação nunca é neutra. Nossa ação é essencialmente política. Nossa ação contribui para tornar o mundo mais humano e justo ou reproduz a ideologia do opressor. Não é possível uma terceira via, pois, “Toda pedagogia está politicamente comprometida socialmente falando, mesmo e talvez, sobretudo, quando nega isso, já que a neutralidade é posição, não falta de posição" (DEMO, 2000, p. 56).

Pensar que a educação é neutra é uma falácia, um mito, uma ilusão. Qualquer processo educativo tem uma intenção política. "O educador, ao definir uma determinada metodologia de trabalho, planeja, decide e produz determinados resultados formativoeducacionais que têm consequências na vida dos educandos e na sociedade onde educador e educandos se encontram". (ZITKOSKI, 2006, p. 51). 
No prefácio da obra de Freire, Educação e Mudança (1979, p. 14), Moacir Gadotti é enfático ao dizer que depois de Paulo Freire ninguém mais pode ignorar que a educação é sempre um ato político. Aqueles que tentam argumentar em contrário, afirmando que o educador não pode "fazer política", estão defendendo uma certa política, a política da despolitização. Pelo contrário, se a educação, notadamente a brasileira, sempre ignorou a política, a política nunca ignorou a educação. Não estamos politizando a educação. Ela sempre foi política. Por isso, é indispensável termos clareza política e ao mesmo tempo consciência de classe.

Ao efetivar um projeto educativo, o educador precisa ter consciência de que lado ele se encontra, pois em uma sociedade marcada pelas desigualdades sociais, nossa atuação pode contribuir para transformar a realidade ou para manter intacto o sistema opressor e excludente. É necessário ter claro que interesses minha ação pedagógica defende. "Não sendo neutra, a prática educativa implica opções, rupturas, decisões, estar com e pôr-se contra, a favor de algum sonho e contra outro, a favor de alguém e contra alguém. E é exatamente este imperativo que exige a eticidade do educador e sua necessária militância democrática a lhe exigir a vigilância permanente no sentido da coerência entre o discurso e a prática". (FREIRE, 1995, p. 39).

Não podemos aceitar o argumento ingênuo da separação entre educação e política. Educar é também politizar. Há uma dialética irrefutável entre o ato político e o ato educativo. A educação não vira política por causa da decisão deste ou daquele educador. Ela é em sua essência um ato político. "Para que a educação fosse neutra era preciso que não houvesse discordância nenhuma entre as pessoas com relação aos modos de vida individual e social, com relação ao estilo político a ser posto em prática, aos valores a serem encarnados" (FREIRE, 1996, p. 125).

A ação educativa não pode deixar de ser política, da mesma maneira que a política a boa política - tem de ser pedagógica. É tão impossível negar a natureza política do processo educativo quanto negar o caráter educativo do ato político. "A necessária e indispensável posição política do educador, para ser coerente com sua ética profissional, é um dos grandes princípios fundantes da pedagogia freiriana e perpassa toda sua obra como educador e filósofo da educação". (ZITKOSKI, 2006, p. 52).

A escola define-se como instrumento de uma luta política para construir relações alicerçadas na democracia e na justiça. A função basilar da escola é político-social. Podemos 
dizer que o núcleo da educação não é constituído pelo espaço pedagógico, mas pela dimensão política. É ingenuidade pensar que a pedagogia nada tem a ver com a política. A opção de despolitizar a educação é uma escolha política e ideológica:

A escola faz política não só pelo que diz, mas também pelo que cala; não só pelo que faz, mas também pelo que não faz. A política é uma prática totalizadora e diária que impregna e dá cor a tudo o que fazemos. Todos nós - cada um em seu trabalho - fazemos política permanentemente, mas o educador a faz de uma maneira privilegiada, já que o Estado coloca à sua disposição um determinado número de futuros cidadãos para que os socialize, quer dizer, para que os politize. (GUTIÉRREZ, 1988, p.22).

A opção política a favor dos oprimidos exige coragem e determinação para denunciar as falácias da globalização neoliberal, que eleva ao máximo os valores do capital e nega, reduz a nada a vida de milhões de seres humanos em todas as sociedades do planeta. Nosso trabalho deve orientar-se no sentido de desconstruir, problematizar os discursos ideológicos dos que a serviço do poder opressor querem nos convencer que a realidade histórica é imutável e que nada podemos fazer para mudar os rumos da globalização econômica. Nossa tarefa é denunciar as ilusões, as contradições do atual modelo, e, por outro lado, anunciar de modo crítico um outro mundo possível, pois sabemos que juntos podemos projetar uma outra globalização, que tenha como centro do seu processo o ser humano e respeito incondicional à vida. Sempre que a educação questiona as estruturas sociais, a ordem vigente, ela se torna um ato político, ou, também, a educação é acima de qualquer pressuposto um trabalho político.

Nossa opção em trabalhar a favor do imperativo da libertação dos oprimidos passa pela denúncia da barbárie representada pelo atual modelo de globalização.

O discurso da globalização que fala da ética esconde, porém, que a sua é a ética do mercado e não a ética universal do ser humano, pela qual devemos lutar bravamente se optamos, na verdade, por um mundo de gente. $O$ discurso da globalização estruturalmente oculta ou nela busca penumbrar a reedição intensificada ao máximo, mesmo que modificada, da medonha malvadez com que o capitalismo aparece na História. O discurso ideológico da globalização procura disfarçar que ela vem robustecendo a riqueza de uns poucos e verticalizando a pobreza e a miséria de milhões. O sistema capitalista alcança no neoliberalismo globalizante o máximo da eficácia de sua malvadez intrínseca. (FREIRE, 1996, p. 144). 
A visão conservadora é fatalista, fechada, e concebe a História, a sociedade, como algo pronto, acabado. Na ideologia burguesa, a sociedade é assim porque tem que ser assim. $\mathrm{Na}$ ótica libertadora, a sociedade é assim porque uma minoria quer que ela seja assim. A realidade é assim, mas pode vir a ser diferente. A mudança é possível. "Mudar é difícil, mas é possível". (FREIRE, 2000, p. 55). A História é o resultado das ações humanas, e por isso pode ser modificada.

A História é o tempo de possibilidade; o futuro é aberto. Enquanto os seres humanos existirem, haverá sonho, luta, desejo, projetos direcionados para a concepção de uma humanidade liberta das forças que interferem na nossa realização histórica. Acreditar no fim da história, no triunfo definitivo do capitalismo, é aderir à visão conservadora e fatalista do neoliberalismo, é deixar-se seduzir pela ideologia conformista dos donos do mundo. "A tarefa progressista é estimular e possibilitar, nas circunstâncias mais diferentes, a capacidade de intervenção no mundo, jamais o seu contrário, o cruzamento de braços em face dos desafios" (FREIRE, 2000, p. 59). Precisamos lutar contra os discursos reacionários dos donos do mundo que decretam a morte dos sonhos e da utopia. "É possível vida sem sonho, mas não existência humana e História sem sonho" (FREIRE, 1995, p. 30).

Em sua constituição ontológica, o ser humano é abertura infinita, é possibilidade inesgotável. Como nos diz Paulo Freire, de modo claro e lúcido: para os educadores progressistas, o amanhã não está prefixado inexoravelmente.

Essa visão de fim da história ou de consolidação de um sistema é uma ilusão antropológica que se transforma em ideologia, e por isso mesmo, que nega a própria condição da história humana. No desdobramento concreto da história, sempre teremos a possibilidade e a exigência de novos embates para libertar a vida de suas próprias limitações e condicionamentos socioculturais (ZITKOSKI, 2006, p.56).

O educador comprometido com a libertação assume a pedagogia ética e utópica direcionada para a mudança social. Mas, para alcançar tal objetivo, é imprescindível manter a crítica permanente em relação a todas as formas de opressão que ameaçam a construção de uma sociedade onde caibam todos e também onde o direito de ser diferente seja respeitado.

Segundo Paulo Freire, a educação pode mudar a condição humana. O grande fim da educação é a realização da vocação ontológica do ser humano: a humanização. Mediante a educação libertadora e comprometida com a humanização das pessoas e sua autonomia 
podemos construir um mundo no qual seja mais fácil amar. A educação deve ter como horizonte o "sonho de um mundo menos malvado, menos feio, menos autoritário, mais democrático e humano". (FREIRE, 1995, p. 30).

A politicidade, inerente à educação, exige a formação para a vivência de uma cidadania militante, como parte de um projeto democrático radical.

Freire ensina-nos que as conexões entre educação e política não podem ser teorizadas apenas em termos de intersecções entre poder e educação, ou exclusivamente em termos das relações entre poder e conhecimento, teorização que, para ser exato, permeou as contribuições de Freire. Ao sublinhar insistentemente a politicidade da educação, Freire impele-nos a compreender as relações entre educação e formação para a cidadania e, particularmente, a esclarecer as raízes ontológicas da educação democrática e dos direitos e responsabilidades dos cidadãos. (TORRES, 1998, p. 60).

Paulo Freire afirma que, do ponto de vista dos interesses dominantes, é fundamental defender uma prática educativa neutra. Aliás, é próprio da educação opressora disfarçar-se de neutra, mistificando a realidade e encobrindo as contradições sociais, fazendo crer que vivemos no melhor dos mundos possíveis. No entanto, os educadores que não fazem política - questionar o poder, denunciar o que temos e anunciar a possibilidade de construirmos um mundo melhor - acabam praticando a política da submissão ao mais forte, legitimando as injustiças e naturalizando a barbárie presente na lógica do mercado. Sua pretensa neutralidade os converte em instrumentos facilmente manejados pelos detentores do poder político e econômico. Portanto, o educador humanista faz a opção política radical pela libertação dos oprimidos, o que implica assumir de modo consciente a dimensão política presente no seu fazer pedagógico.

Opção política é tomar partido frente à realidade social, é não ficar indiferente ante a justiça atropelada, a liberdade infringida, os direitos humanos violados, o trabalhador explorado. Tomar partido pela justiça, pela liberdade, pela democracia, pela ética, pelo bem comum, é opção política, é o fazer político. (GUTIERREZ, 1988, p. 44- 45).

Testemunhamos, a partir da revisão de literatura, que o pensamento políticopedagógico de Paulo Freire tem como base a radicalidade ético-política, colocando-se a favor e a serviço da transformação social, na perspectiva da humanização do mundo. Nos livros Pedagogia do Oprimido e Pedagogia da Esperança, podemos destacar os desafios da 
luta (processual e permanente) por uma Educação Popular libertadora, cuja formação éticopolítica não é neutra. A pedagogia libertadora, conforme Freire (1992; 2013), pressupõe a emancipação dos sujeitos na defesa dos oprimidos, aqueles "que estão proibidos de ser". Para ele, a educação capitalista é desumanizadora e opressora porque gera exclusão das condições mínimas de dignidade e impede a pessoa de desenvolver-se em sua autonomia.

Freire (2013) compreende por ser humano o sujeito histórico, incompleto e inconcluso. Afirma, no segundo capítulo da Pedagogia do Oprimido, que a vocação ontológica dos seres humanos para ser mais para a humanização. À vista disso:

\begin{abstract}
A educação não pode estar desligada da política, pois educar implica necessariamente perguntar-se pelo tipo de sociedade que desejamos. E isso é um ato político. Se a educação é a "inserção" das pessoas na sociedade, ela tem que se perguntar: em que tipo de sociedade? Simplesmente nessa que está aí, pelo simples fato de estar aí? Ou a discussão sobre projeto de sociedade também faz parte da educação? Em outras palavras: educar para que sociedade? (GUARESCHI; BIZ, 2005, p. 30).
\end{abstract}

Esta noção de que a educação é inseparável da política é uma das questões mais férteis do legado de Paulo Freire ao pensamento pedagógico do século XX. Não há educação sem política e nem política que não seja ao mesmo tempo educativa /pedagógica.

\begin{abstract}
Um processo educativo deve incluir o lado político, que envolva a produção do conhecimento voltado para o pensar crítico, para melhor agir. Tal visão inclui a intervenção do subjetivo no objetivo, antecipando a nova sociedade que se quer, aprofundando a consciência da dignidade do ser humano, aberto ao diálogo. Se educar é conscientizar, a educação é um ato essencialmente político. Ninguém educa ninguém sem uma proposta política, seja qual for. É o grau de consciência política que define se somos ou não educadores. (GUARESCHI; BIZ, 2005, p. 31).
\end{abstract}

Na condição de sujeito inconcluso, histórico e político, Freire (1992; 2013) reconhece que na luta de classes (opressor versus oprimido) se faz necessário e urgente processos de formação por meio da consciência política da nossa vida em sociedade. Em consonância com sua pedagogia, a transformação do mundo implica processos de construção de conhecimentos voltados para o pensar crítico, articulando a denúncia da desumanização/opressão e o anúncio da humanização/libertação. Dessa dialética (denúncia e anúncio) deveria emergir uma nova realidade, considerada por Freire (1992) compromisso esperançoso e ético-político de educadores progressistas, pois cabe a nós o "[...] futuro a ser 
criado, construído, política, estética e eticamente, por nós, mulheres e homens. A utopia implica essa denúncia e esse anúncio [...]. (FREIRE, 1992, p. 91).

Guareschi e Biz (2005) convergem com Paulo Freire $(1992 ; 1996)$ na necessidade da reinvenção da educação e do projeto de sociedade, alertando-nos que as bases para construir a educação libertadora são: 1) o reconhecimento da disputa entre projetos antagônicos de educação ( capitalista neo e ultraneoliberal versus socialista democrático); 2) a ética do ser mais para a humanização; e, 3) o reconhecimento de que a educação é um ato político. Essas bases são indispensáveis ao projeto de transformação social na direção da emancipação humana.

\section{A POLITICIDADE EM TEMPOS DE ULTRANEOLIBERALISMO: EDUCAÇÕES EM DISPUTAS}

O ultraneoliberalismo é a face mais perversa do neoliberalismo, presente no movimento anti-cientificismo e anti-humanidade, preceitos presentes no atual governo brasileiro. Milton Friedman (1977), através da chamada Escola de Chicago, é o inspirador principal da posição política e teórica do ultraliberalismo, supervalorizando a privatização de todos os serviços públicos, incluindo as políticas sociais, como é o caso da educação.

Na América Latina, este modelo ultraneoliberal foi adotado no Chile, no período da ditadura de Pinochet, com argumentos de modernização da sociedade chilena e implantação de um modelo que transportasse para a iniciativa privada amplos setores onde o Estado deveria investir, como educação, saúde, transporte, previdência, com a perspectiva de que reduziria o déficit público, gerando superávit fiscal, o mesmo discurso do atual governo brasileiro.

A dimensão ultraneoliberal, no governo atual, se concretizou na Reforma da Previdência e Reforma Fiscal; atualmente, existe uma tentativa, ainda não concretizada, de privatização de diversos setores onde o Estado tem participação.

No que tange a educação, ela é expressa nas Reformas Educacionais como o-desmonte da Constituição Federal de 1988 e no empenho pela implementação do projeto "Future-se". Este, por sua vez, é um braço do projeto de desestatização da educação, seja pelo caminho da privatização ou pelo regime de parceria público-privada, transformando as instituições estatais em organizações sociais. Com esses projetos de viés mercadológico, Paulo Freire e 
suas concepções de educação, ser humano e sociedade são descartadas pelo projeto de um regime antidemocrático e reacionário.

Para entender essa opção político-econômica faz-se necessário voltar ao velho Marx, onde ele apresenta que o viés estruturante do capitalismo é a mais valia, ou seja, o momento em que o capital se apropria do excedente produzido pelo trabalho. No caso do ultraneoliberalismo, a mais valia está presente não só no excedente do trabalho, mas na minimização do tamanho do Estado, onde os recursos públicos arrecadados através dos impostos, ao invés de retornarem em forma de investimentos na educação, saúde, infraestrutura, são direcionados para o mercado financeiro, e isso se chama mais valia social. No caso da mais valia social, os recursos dos impostos do Estado são carreados para o Mercado Financeiro; no seu livro "A era do capital improdutivo", o professor Ladislau Dowbor apresenta claramente como este capital financeiro se aproveita dos recursos do Estado.

O sistema financeiro internacional funciona a pleno vapor. A cultura da intermediação financeira não varia muito entre a City de Londres, Wall Street ou o sistema de usura que se implantou no Brasil. Existe uma cultura financeira global. No caso brasileiro, o desajuste fica evidente quando constatamos que, a partir de 2014, o PIB caiu drasticamente, enquanto os juros e os lucros dos intermediários financeiros aumentavam entre $20 \%$ e $30 \%$ ao ano. Nosso sistema de intermediação financeira não serve à economia, e sim dela se serve. É produtividade líquida negativa. A máquina financeira está vivendo à custa da economia real. (DOWBOR, 2017. p. 154)

Dessa forma, podemos entender que as corporações transnacionais e gigantes financeiros, operando em escala mundial, agem nas nações, com governos nacionais impotentes frente aos fluxos econômicos dominantes. Não existindo instrumentos políticos que controlem esse mercado financeiro, tornando o Estado inseguro, abrindo espaço para governos reacionários e de ultra direita, que estão a serviço deste grande capital financeiro. (DOWBOR, 2017)

Acerca da compreensão política de formação do homem, segundo a concepção de economistas neoliberais, é necessário formar o homem econômico (homo economicus), o qual é fruto da instrução escolar como responsabilidade do indivíduo, geradora de valores econômicos para si e para o desenvolvimento do capitalismo.

Em “Capitalismo e Liberdade" (FRIEDMAN, 1977), localizamos as normas do mercado sob a lógica da liberdade do capital, que é sinônimo de heteronímia das políticas sociais 
rumo à privatização e mercantilização da vida em sociedade, incluindo o retorno a ações voluntárias de cunho assistencialista / benevolente.

A liberdade política para Friedman (1977) é o livre mercado e o desenvolvimento das instituições capitalistas, incluindo a educação como serviço a ser comercializado. Faz crítica às instituições educacionais públicas e gratuitas, e coloca o Estado como avaliador:

Nossos princípios não fornecem uma linha clara e definida de demarcação
quanto ao uso apropriado da ação governamental para realizar em
conjunto o que é importante a cada um de nós realizar individualmente por
meio da troca estritamente voluntária. Em cada caso particular em que se
proponha a intervenção, devemos organizar uma folha de verificação,
anotando separadamente as vantagens e desvantagens. (FRIEDMAN, 1977.
p 21).

Friedman (1977), um dos teóricos sustentadores do atual projeto governamental brasileiro, se posiciona contra as políticas sociais, postura essa que, no caso brasileiro, se reflete em ações de oposição ao Paulo Freire como inspirador de uma educação como prática da liberdade na perspectiva do "socialismo realmente democrático" (FREIRE, 2015, p.39).

O projeto econômico institucional de um regime ultraneoliberal propõe a atuação do Estado a serviço da economia capitalista, objetivando implementar uma nova ordem econômica, tendo como pilar o desmonte das políticas sociais e da democracia. Desse modo, são abolidos todos os entraves para o desenvolvimento livre da economia de mercado, cuja democracia é, na acepção ultraneoliberal, um bloqueio para o processo crescente e unificado do livre mercado.

No Brasil, desde a década de 1990, no caso particular das políticas educacionais, podemos citar a influência do Banco Mundial, via empréstimos (financiador), e do Todos pela Educação, por meio de assessorias e documentos orientadores com a difusão de suas ideias. Coraggio (1996) e Haddad (1998) declaram que a reforma educacional via orientações/documentos dos organismos internacionais, sob apoio das orientações economicistas, destina-se ao desenvolvimento econômico capitalista, definindo metas e estratégias educacionais.

Freire (1996) nos alerta para os discursos de uma falsa democratização da educação, pois muitos projetos ocultam o caráter "social, político e econômico da classe dominante". (GADOTTI, 1982, p. 31). 
Ao analisarmos tais propostas (Banco Mundial e Todos pela Educação), observamos a aparência de uma democracia por intermédio de discursos como diminuição da extrema pobreza e direito à educação. Nestes casos, à luz do neoliberalismo, ainda se valoriza a intervenção estatal na educação via execução das políticas sociais. No tocante a faceta ultraneoliberal, a intervenção estatal dá-se via avaliação e fiscalização, negando-se a prestar serviços de execução de políticas sociais, transferindo essas ações ao mercado (privatização) ou quase mercado (organizações sociais - terceira via). Evangelista e Shiroma (2006) explicitam esse tipo de educação como alívio da pobreza - tópico presente na agenda neoliberal. Tanto no neoliberalismo como no ultraneoliberalismo, a hegemonia do capital é o projeto de sociedade, daí a formação do homem econômico: a educação tendo o papel principal da formação do capital humano (SCHULTZ, 1973; FRIGOTTO, 1993).

A área da educação, em tempos de globalização excludente, tem nos organismos multilaterais as perspectivas educacionais neo-tecnicistas, destinadas à mundialização do capitalismo em suas mais diversas versões. O contexto de globalização excludente é considerado como a face malvada do capitalismo (FREIRE, 1996), pois se apresenta perversa sob a lógica do ser menos para a desumanização. Um exemplo desta perversidade é a da responsabilização do indivíduo pelas desigualdades sociais. Nessa lógica, quem "conquista" o mínimo de dignidade (ter emprego ou acesso à educação) é considerado um vencedor, pois atingiu seu "sucesso" por mérito próprio. Observa-se aí a ausência da criticidade ao modelo capitalista de educação e sociedade, que, ao atribuir o "sucesso" ao mérito individual, tira do sistema a responsabilidade sobre toda a parcela da sociedade que não alcançou lograr o mesmo êxito. Ao se valer de determinados conceitos e discursos para manipular sentidos ocultando responsabilidades, o sistema capitalista manifesta a perversidade de um modelo de educação e sociedade altamente excludente.

$\mathrm{Na}$ perspectiva educacional tecnicista (tradicional), concernente à questão pedagógica, a educação bancária não se apresenta de maneira aparente. Alguns exemplos demonstram a educação tecnicista presente nas relações humanas, profissionais, culturais políticas e sociais, tais como:

1. Educação sob o domínio da tecnocracia: considera-se o saber neutro e organizado de modo hierárquico. Desrespeito à linguagem e aos saberes populares. A ciência colonial como único e aceito saber científico-técnico. 
2. Instituições educacionais: produzem comunicados a partir de uma escola distante das relações da vida concreta dos estudantes; no currículo, constata-se a fragmentação das disciplinas.

3. Pedagogia capitalista e currículos escolares: separam a teoria da prática, e a educação é concebida como meio de modelar as pessoas, por intermédio dos ditames do capitalismo, conjugando os valores individualistas e competitivos.

4. Pedagogia conservadora - nega a pluralidade de saberes, a diversidade, e a multiculturalidade.

Nas perspectivas educacionais neo-tecnicistas, alguns dos valores e concepções tecnicistas tradicionais se mantêm, e outros são refundamentados, especificamente:

1. O retorno do racionalismo: na formalização da Pedagogia das Competências, por meio da Base Nacional Comum Curricular, e dos manuais/apostilamentos como ferramenta pedagógica de enquadramento do trabalho docente. Racionalidade instrumental.

2. Meritocracia e individualismo: Acesso e permanência na educação universitária são considerados mérito individual. Indivíduos passam a ter responsabilidade pelo seu sucesso ou seu fracasso. As desigualdades sociais são resultado da incompetência do indivíduo. Pessoas de sucesso são e devem ser recompensadas. Mérito e eficiência como resultado de maior produtividade em menor tempo.

3. Desigualdades escolares: instrumentalização do trabalho docente via avaliações de larga escala com fins de aferir resultados estatísticos. Flexibilização das relações de acesso, de permanência e de conclusão por meio da Educação a Distância, com o uso excessivo de equipamentos tecnológicos, substituindo contato presencial do professor. Privatização e terceirização da educação.

4. Retorno de teorias comportamentalistas: Desenvolvimento da Inteligência Emocional como parte do currículo, mediante atividades motivacionais e produção de habilidades de liderança e de formação de profissionais flexíveis e empáticos, aprendendo a controlar/administrar suas emoções. 
É nesse sentido que Paulo Freire (2000) nos desafia a uma educação para libertação associada à intervenção no mundo. Para a pedagogia de Freire, a politicidade do ato educativo não está dissociada de uma proposta democrática de educação e de sociedade. Como proposta teórico-metodológica, apresenta a Educação Popular humanizadora, incompatível com a educação capitalista. A opção pela educação como humanização é radicalmente oposta ao ultraneoliberalismo consubstanciado por uma pedagogia das competências via neotecnicismo. Com essa posição, Freire (1996; 2000) reprova as leis do mercado que reforçam valores como competição, individualismo, meritocracia e suposta neutralidade da educação. Por isso, a "intervenção no mundo, segundo Freire (1996), é um ato político com dimensão ética, estética e epistemológica." (PAULO; MIRA, 2018, p.277).

A educação libertadora, incompatível com os princípios do tecnicismo e neotecnicismo, defendida por Paulo Freire, vislumbra uma sociedade democrática, resultante de processos construídos pelo respeito à diversidade, pelo multiculturalismo, pela participação e pelo diálogo crítico entre os diversos saberes, cujo objetivo é ir consolidando a construção de uma sociedade socialista.

\section{EDUCAR É POLITIZAR E CONSCIENTIZAR}

O conceito conscientização remete à esfera do conhecer e também da ação efetiva, comprometida política e eticamente com a transformação social. A educação humanizadora exige a coragem de intervir no mundo.

Em conformidade com Freire (1996), a nossa presença no mundo não é a de quem a ele se adapta, mas a de quem nele se insere. "É a posição de quem luta para não ser apenas objeto, mas sujeito também da História." (FREIRE, 1996, p.60). Aprender para o ser humano é sempre uma experiência criadora: constatar para mudar. Por isso, a prática educativa é um ato político, isto é, "Ninguém pode estar no mundo, com o mundo e com os outros de forma neutra" (FREIRE, 1996, p. 86).

O processo infinito de conscientização constitui-se numa leitura crítica da realidade, comprometida com a ação ética e política, na busca de uma nova sociedade pela via da mudança social. O caminho para uma nova sociedade exige a tomada de consciência das condições históricas. Pessoas conscientes não são manipuladas e têm a possibilidade de se engajarem na luta visando à transformação histórica. A conscientização e a manipulação são 
inconciliáveis. O sonho de um mundo melhor requer nossa decisão e o compromisso ético de irmos à luta para criá-lo.

A conscientização se autentica nesta ida e volta que é, em última análise, a
unidade dialética entre prática e teoria, em que aprendemos que a
verdadeira paciência não se identifica, jamais, com a espera na pura espera.
A verdadeira paciência, associada sempre a autêntica esperança,
caracteriza a atitude dos que sabem que, para fazer o impossível, é preciso
torná-lo possível. E a melhor maneira de tornar o impossível é realizar o
possível hoje. (FREIRE, 2011, p. 98).

Conscientização implica compromisso, engajamento, ação política visando à mudança. Conhecer mais para ser mais e inserir-se no mundo para mudar o que desumaniza. É fundamental que o ser humano oprimido se dê conta de seu papel e potencial na transformação da história. "O comprometimento não é um ato passivo, mas implica o conhecimento crítico da realidade, pois requer não apenas a consciência dessa realidade, mas também a consciência da capacidade do próprio sujeito em transformá-la" (FREITAS, 2001, p. 154).

$\mathrm{O}$ ato de conscientizar não pode estar desvinculado de uma ação engajada e comprometida com os valores humanistas. Só quem conhece o mundo pode agir para transformá-lo. Homens e mulheres não podem participar ativamente na história, na sociedade, na transformação da realidade, se não forem despertados para a tomada de consciência da realidade em que se encontram e de sua capacidade para transformá-la. A educação é sempre um ato de conhecimento, uma aproximação crítica da realidade, que política e eticamente exige o passo seguinte: agir para transformar; inserção crítica do sujeito na história. "A tarefa fundamental, essencial, indispensável da educação é propiciar às pessoas esse processo de libertação: crescer em consciência, para nos tornarmos mais livres e autenticamente responsáveis" (GUARESCHI; BIZ, 2005, p. 21).

Para Freire, a educação humanista é um ato de intervenção ética no mundo. Neste sentido, a consciência se constitui como consciência do mundo e de suas possibilidades.

A consciência do mundo e a consciência de si crescem juntas e em razão direta; uma é a luz interior da outra, uma comprometida com a outra. Evidencia-se a intrínseca correlação entre conquistar-se, fazer-se mais a si mesmo, e conquistar o mundo, fazê-lo mais humano. (FIORI, 1987, p. 15). 
O ser humano é fundamentalmente desejo de ser. Para que este projeto de ser mais se efetive na história é necessário criar as condições estruturais, o que implica um contexto político, social e cultural. Se as condições sociais proíbem o ser humano de se realizar em sua vocação ontológica, é um imperativo ético da educação libertadora trabalhar para desenvolver o pensamento crítico, a autonomia intelectual, para que cada pessoa assuma seu lugar na história como sujeito comprometido com a transformação social. Não há conscientização sem desvelamento da realidade.

É, pois, através da conscientização que o homem assume o papel de sujeito e o seu compromisso histórico num processo de fazer e refazer o mundo, dentro de possibilidades concretas, fazendo e refazendo também a si próprio. Tal processo exige ação-reflexão em movimento permanente de superação da posição ingênua frente à realidade, aquela que ocorre na forma espontânea de aproximação do mundo. Exige a assunção de uma posição crítica, para além da tomada de consciência, uma vez que a tomada de consciência não é ainda conscientização, porque esta consiste no desenvolvimento crítico da tomada de consciência. A conscientização exige o engajamento da ação numa perspectiva transformadora, de modo que não para, estoicamente, no reconhecimento puro, de caráter subjetivo, da situação, mas, pelo contrário, prepara os homens, no plano da ação, para a luta contra os obstáculos à sua humanização. (FREITAS, 2001, p. 151).

A libertação-humanização verdadeira não é uma coisa que se deposita nos homens e mulheres. Numa perspectiva freiriana, as práticas teórico-práticas revelam o potencial da construção de uma Pedagogia da libertação a partir da Educação Popular que tem como base o diálogo crítico-problematizador e emancipatório.

Desenvolver o máximo de consciência possível; apropriar-se do real e inserir-se de forma cada vez mais lúcida na transformação das estruturas que oprimem. É algo importante perceber que a realidade social é transformável; que, feita pelos homens, mulheres, por eles pode ser mudada; que não é algo intocável, um fatalismo, uma sina, diante de que só houvesse um caminho: a acomodação a ela. História é possibilidade, um vir a ser; abertura para o novo; esperança de que uma nova realidade é sempre possível. A desumanização, que resulta de uma ordem injusta, não é causa de desesperança, mas de esperança, e nos desafia a procurar sem cessar a humanização que a injustiça, a opressão e o autoritarismo negam aos homens e mulheres.

Na perspectiva de Freire, a educação humanista só é viável a partir da superação das estruturas opressoras que geram a desumanização. Não há outro caminho para a 
humanização a não ser uma autêntica transformação, que implica a superação das estruturas que oprimem e desumanizam. Ao voltarmos nosso olhar para a História, não só do Brasil, mas de muitos países da África, da América Latina e da Ásia, percebemos com assombro um cenário de barbárie, horror e violência. Frente a essa realidade, a tarefa principal da educação se volta para a superação dessa lógica de violência, autoritarismos, ausência de democracia e injustiças sociais. É nessa perspectiva que entendemos a preocupação de Adorno em torno da educação, pois julgamos que há afinidades com o pensamento de Freire em suas dimensões mais profundas. Esse aparente desvio se justificará no final do texto. Adorno, no escrito: "Educação após Auschwitz" (1995), anuncia o novo imperativo para a educação.

\footnotetext{
A exigência que Auschwitz não se repita é a primeira de todas para a educação. Qualquer debate acerca de metas educacionais carece de significado e importância frente a essa meta: que Auschwitz não se repita. (ADORNO, 1995, p. 119).
}

O medo de uma regressão à barbárie preocupa Adorno, e impõe um dever ético à educação: trabalhar para impedir que nada parecido com o que representou Auschwitz volte a acontecer. Educar é lutar contra a barbárie, o horror e as circunstâncias que agridem a dignidade humana. Precisamos nos darmos conta que a barbárie se encontra no próprio princípio civilizatório e trabalharmos por um novo futuro, livre desta ameaça. Educar é apostar na possibilidade da humanização, da autonomia crítica e no progresso moral capaz de instaurar relações humanas alicerçadas na democracia, na justiça social e na cultura dos direitos humanos, que possibilitam a convivência de todas as culturas que contribuem para preservar a dignidade singular de cada ser humano.

Em Paulo Freire, a educação humanista e libertadora está relacionada ao processo educativo entendido como conscientização e todas as implicações desse projeto infinito, que visa criar condições epistemológicas, políticas, históricas e éticas para que o oprimido se transforme em sujeito de sua libertação. Não é possível mudar, transformar, revolucionar, chegar a outro mundo possível sem o alargamento da consciência crítica, sem a politização das pessoas para que assumam seu lugar no mundo como sujeitos protagonistas de sua história. Educação é um ato de conhecimento e desvelamento crítico da realidade. 
A conscientização, enquanto processo permanente de construção da criticidade, para além de sua dimensão política, implica necessariamente uma dimensão epistemológica, uma vez que a consciência crítica, ao não se satisfazer com as aparências, nem aceitar explicações mágicas sobre a realidade, pressupõe uma atitude de inquietação e busca de compreensão dos fatos, ultrapassando os limites da cotidianidade e exigindo que o pensamento opere epistemologicamente. Logo, a curiosidade torna-se epistemológica, característica fundante da consciência crítica, a qual não se reduz à tomada de consciência, mas implica, principalmente, a assunção de sua condição de sujeito histórico. Nesse processo, no exercício permanente da capacidade de conhecer-se, através da criticização das relações consciência-mundo, o sujeito contribui para a transformação da realidade à medida que transforma também a si mesmo. (FREITAS, 2001, p. 73).

Aprender é compreender as razões de ser do mundo, suas contradições e possibilidades, e intervir, agir para transformá-lo.

O que nos parece indiscutível é que, se pretendemos a libertação dos homens e mulheres, não podemos começar por aliená-los ou mantê-los alienados. A libertação autêntica, que é a humanização em processo, não é uma coisa que se deposita nos homens e mulheres. [...]. (FREIRE, 1987, p.67).

A essência da educação em Freire é um processo permanente que visa humanizar a pessoa singular e a sociedade. Seu projeto é coletivo: libertar oprimido e opressor. Estruturas injustas desumanizam o opressor e o oprimido. A formação de um pensamento ético-político alicerçado na autonomia intelectual é ponto central da pedagogia da libertação. Quanto mais crítico mais capaz o ser humano se torna para intervir no mundo.

Mais que escrever e ler, os alfabetizandos necessitam perceber a necessidade de um outro aprendizado: o de escrever a sua vida, o de ler a sua realidade, o que não será possível se não tomam a história nas mãos para, fazendo-a, por ela serem feitos e refeitos" (FREIRE, 2011, p. 20).

O conhecimento crítico da realidade deve engajar a pessoa na luta pela mudança das estruturas que impedem o humano de ser, pois, não há humanização na opressão, assim como não pode haver desumanização na verdadeira libertação. Mas, por outro lado, a libertação não se dá dentro da consciência dos homens e mulheres, isolada do mundo, senão na práxis do ser humano enquanto sujeito dentro da história concreta, que, implicando a relação consciência-mundo, envolve a consciência crítica desta relação. 
A intuição fecunda de Freire que perpassa todo seu pensamento pedagógico, filosófico e antropológico é a ideia de conscientização como impulso para a transformação interna da pessoa (alcançar o máximo possível de consciência crítica) que se efetiva na autonomia do sujeito, na liberdade e no compromisso histórico com a transformação das estruturas, tendo como critério o ser humano e seu desejo de humanização. Nessa perspectiva, educar é conscientizar; é desenvolver o pensamento crítico e, a partir dessa dimensão, caminhar na direção da libertação, da humanização, da autonomia, da condição de sujeito da história, engajado na práxis transformadora. O sujeito histórico, o agente de mudança é o próprio oprimido, que, pela consciência crítica, comprometida politicamente e com a utopia ética da humanização, emerge como sujeito capaz de fazer uma nova história, livre da opressão desumanizadora. É o processo de conscientização que cria as condições históricas para a mudança das estruturas opressoras que negam o ser humano e impedem que ele se realize como sujeito vocacionado para o ser mais.

A conscientização produz a desmitologização. $O$ trabalho humanizante não poderá ser outro senão o trabalho de desmitificação. Por isso mesmo a conscientização é o olhar mais crítico possível da realidade, que a desvela para conhecê-la e para conhecer os mitos que enganam e que ajudam a manter a realidade da estrutura dominante. (FREIRE, 1980, p. 29).

A conscientização não pode existir fora da práxis, da ação-reflexão, do diálogo amoroso, do direito de pronunciar o mundo pela palavra e do compromisso ético-político com a mudança das estruturas que geram opressão. Toda compreensão autêntica da realidade ou do mundo é também práxis revolucionária. Saber para transformar. A conscientização não pode parar na etapa do desvelamento da realidade. $O$ ato de conhecimento, do desvelamento da realidade, somente tem sentido se estiver orientado numa ação política sobre a mesma, no sentido de modificá-la, sem a qual os homens e mulheres não podem alcançar sua humanização. Nessa perspectiva, podemos dizer que, para Freire, a educação autêntica é sempre um instrumento a serviço da libertação, da humanização, do ser mais, da democracia, da ética universal do ser humano, da justiça social, da fraternidade e de uma cultura dos direitos humanos em esfera planetária. Através da educação é possível efetivar uma nova sociedade; um mundo humanizado com estruturas que convergem para a realização da nossa vocação ontológica direcionada para o ser mais, ser gente na convivência com a pluralidade de gentes em espírito de fraternidade solidária. 
A verdadeira revolução é um ato de libertação, de criação e de amor. Não se faz revolução sem amor pelos seres humanos e pelo mundo; sem a utopia de um mundo mais democrático, justo e com as estruturas direcionadas para realizar nossa vocação ontológica orientada ao ser mais.

É tarefa da educação comprometida com a libertação-humanização trabalhar a esfera política, estética, emocional, ética, social, cultural e antropológica. Educar é sempre um ato político. Mas, além disso, é essencial trabalhar a sensibilidade, a ética, a esperança e o sonho de um novo mundo. A concretização da humanização, enquanto vocação ontológica dos seres humanos, é um movimento histórico que não se efetiva sem utopias, esperanças, lutas e confiança nos homens e mulheres em seu agir para fazer deste mundo um espaço-tempo mais fraterno, em que seja menos difícil amar.

\section{CONSIDERAÇÕES PRELIMINARES}

Como conclusão provisória, podemos dizer que o educador político faz da educação um espaço de luta permanente contra a globalização econômica capitalista, que é necrófila na sua essência.

Freire (2013) apresenta a tese da ética universal do humano (ser mais), tendo a vida como seu valor central, para a nossa existência e resistência. Frente a sua concepção de história como possibilidade, a realidade pode ser transformada. Entretanto, a omissão da luta contra a opressão é um tipo de ação. Em nossa relação com o mundo, podemos agir em prol da humanização e contribuir para que mudanças sociais aconteçam; ou omitir as relações opressor-oprimido, e, assim, impedirmos que as transformações se realizem.

São dois projetos em disputa: o socialismo democrático e o capitalismo; e, para a luta em defesa de um desses projetos, precisamos ter a ciência de que a neutralidade é impossível. O não se meter ou falar em política já é uma atitude política. Nessa perspectiva, o educador autêntico precisa assumir a politicidade inerente à educação, pois todo o processo educacional constitui-se em um ato essencialmente político, onde não há, de fato, neutralidade diante dos contextos concretos em que se situam os seres humanos, enquanto sujeitos sociais, cidadãos e seres ético-políticos de decisões. Se fosse o contrário, nossa ação não é educação, ou torna-se simplesmente ideologia que reproduz a opressão e nega o 
humano em sua vocação ontológica, que se concretiza na luta para superar as condições que nos atrofiam na existência de nosso ser mais.

O pensamento antropológico, filosófico e pedagógico de Paulo Freire assume o compromisso com a nossa vocação ontológica direcionada para o ser mais. Daí que o processo educativo, na perspectiva da pedagogia crítica, apresenta possibilidades de transformação social, levando em consideração a "dialogação do homem/mulher sobre o mundo e com o mundo mesmo, sobre os desafios e problemas, que o faz histórico" (FREIRE, 1976, p. 68). Assim sendo, na sua pedagogia e filosofia não é possível a separação entre educação e política. As suas reflexões contribuem para o debate crítico sobre políticas educacionais em tempos de tentativa de consolidação de um projeto de sociedade ultraneoliberal e de suas pedagogias neotecnicistas, que pretendem retirar da educação seu potencial crítico, humanizador e ético - reforçando a racionalidade meramente instrumental.

O triunfo exclusivo da racionalidade tecnológica significa uma atrofia fundamental da dimensão ética da vida. A esfera do prático se identifica agora com a esfera do técnico: trata-se da mais radical cientifização da vida humana, que se traduz no ideal da tecnificação plena, o que iria significar que os mecanismos de regulação da vida dos homens poderiam garantir a realização e a consecução de determinados fins sistêmicos, que conduzem a um processo de autoconservação, o que significa dizer a eliminação do homem. Quanto menos o homem pensa, menos exerce sua capacidade de reflexão crítica, tanto melhor o sistema funciona, conserva-se e se reproduz. A racionalização da vida humana significa a submissão total do homem à lógica da racionalidade do controle e da manipulação: o próprio homem se integra ao aparato técnico. (OLIVEIRA, 1995, p. 90).

Das teses centrais de Freire, podemos ratificar que a politicidade e as classes sociais estão presentes nas suas obras. Isso significa que o educador não teve dúvidas sobre os projetos antagônicos em disputas. Se adentrarmos a sua literatura, presenciaremos a politicidade como tese corporificada ao debate das classes sociais.

Em conformidade com Freire (1992), a educação não pode ser analisada de modo descontextualizado, deixando evidenciado que humanização e libertação são lutas necessárias para a superação das relações objetivas e subjetivas da classe opressora. Consequentemente, o projeto humanizador /libertador é uma luta de classe - da classe oprimida.

A superação da sociedade de classes exige conceber que toda educação é um ato político, problematizando todo discurso da pseudoneutralidade da ação educativa. Na contemporaneidade, a globalização excludente, na abordagem ultraneoliberal, nega a 
existência de possibilidade de um novo mundo possível, isto porque a vertente da educação crítica-problematizadora, de uma ciência e política biófila, questiona e enfrenta, constantemente, a educação capitalista, que tenta nos convencer que não há alternativas fora da sua lógica e que a História chegou ao fim (fatalmente, temos que aceitar e resignarmo-nos ao que está aí).

Enquanto educação libertadora ou Educação Popular, o trabalho educativo acompanha processos de transformação educacional, social, política, cultural e econômica das sociedades, desde os contextos locais, nacionais e regionais. A justiça social vinculada à democracia, sob a perspectiva da opção ética, pedagógica e política emancipatória, reconhece a dimensão política emancipatória como bandeira de luta.

A pedagogia e filosofia da libertação se tornaram uma ameaça ao paradigma que naturaliza as desigualdades sociais, especialmente porque sonho e esperança têm sido o alimento de educadores que apostam e lutam por um outro mundo possível, necessário e urgente.

\section{REFERÊNCIAS}

ADORNO, T. W. Educação e emancipação. Rio de Janeiro: Paz e Terra, 1995.

CORAGGIO, J. L. Propostas do Banco Mundial para a educação: sentido oculto ou problema de concepção? In: DE TOMMASI, L.; WARDE, M. J.; HADDAD, S. (orgs.). O Banco Mundial e as políticas educacionais. São Paulo: Cortez; PUC-SP; Ação Educativa, 1996, p. 75-124.

DEMO, P. Ironias da educação - mudanças e contos sobre mudança. Rio de Janeiro: DP\&A, 2000.

DOWBOR, L. A era do capital improdutivo: Por que oito famílias tem mais riqueza do que a metade da população do mundo. Autonomia Literária, São Paulo. 2017.

EVANGELISTA, O; SHIROMA, E. O. Educação para o alívio da pobreza: novo tópico da agenda global. Revista de Educação PUC Campinas, Campinas, n. 20, p. 43-54, jun. 2006.

FIORI. E. Aprender dizer sua palavra [Prefácio]. In.: Pedagogia do Oprimido. Rio de Janeiro: Paz e Terra, 1987.

FIORI, E. M. Educação e Política: textos escolhidos / vol. 2. Porto Alegre: Editora da UFRGS, 2014.

FREIRE, P. Educação como prática para a liberdade: e outros escritos. Rio de Janeiro: Paz e Terra, 1976. 
FREIRE, P. Educação e mudança. Rio de Janeiro: Paz e Terra, 1979.

FREIRE, P. Conscientização: teoria e pratica da liberdade: uma introdução ao pensamento de Paulo Freire. São Paulo: Editora Moraes, 1980.

FREIRE, P. Pedagogia da esperança: um reencontro com a Pedagogia do oprimido. Rio de Janeiro: Paz e Terra, 1992.

FREIRE, P. Política e educação: ensaios. São Paulo: Cortez, 1995.

FREIRE, P. Pedagogia da Autonomia: saberes necessários à prática educativa. São Paulo: Paz e Terra, 1996.

FREIRE, Paulo. Pedagogia da indignação: cartas pedagógicas e outros escritos. São Paulo: Editora UNESP, 2000.

FREIRE, P. Ação cultural para a liberdade e outros escritos. Rio de Janeiro: Paz e Terra, 2011.

FREIRE, P. Pedagogia do oprimido [recurso eletrônico] - 1. ed. - Rio de Janeiro: Paz e Terra, 2013.

FREIRE, P. À sombra desta mangueira [recurso eletrônico]. 11.ed. - Rio de Janeiro: Paz e Terra, 2015.

FREITAS, A. L. S. de. Pedagogia da conscientização: um legado de Paulo Freire à formação de professores. Porto Alegre: EDIPUCRS, 2001.

FRIEDMAN, M. Capitalismo e liberdade. [sol.]: Arte nova, 1977.

FRIGOTTO, G. A produtividade da escola improdutiva. Um (re) exame das relações entre educação e estrutura econômico-social capitalista. 4åed. São Paulo: Cortez, 1993.

GADOTTI, M. Educação e ordem classista (Prefácio). In.: FREIRE, P. Educação e mudança. Rio de Janeiro: Paz e Terra, 1979. p. 9-14

GADOTTI, M. Educação e poder: introdução à pedagogia do conflito. São Paulo: Cortez, 1982.

GUARESCHI, P A, e BIZ, O. Mídia, Educação e Cidadania: Tudo o que você deve saber sobre mídia. Petrópolis, RJ: Vozes, 2005.

GUTIÉRREZ, F. Educação como práxis política. São Paulo: Summus, 1988.

HADDAD, S. Os Bancos multilaterais e as políticas educacionais no Brasil. In: VIANNA JR., A. (ed.). A estratégia dos bancos multilaterais para o Brasil. Brasília: Rede Brasil, 1998. p. 41-52.

OLIVEIRA, M. A. Ética e práxis histórica. São Paulo: Ática, 1995. 
PAULO, F. dos S.; MIRA, L. N. de. Intervenção no mundo. In.: STRECK, Danilo; REDIM, Euclides; ZITKOSKI, Jaime. Dicionário Paulo Freire. Belo Horizonte: Autêntica, 2018. (p. 275277).

TORRES, C. A. Diálogo com Paulo Freire. São Paulo: Edições Loyola, 1979.

TORRES, C. A. A Pedagogia Política de Paulo Freire. In: APPLE, M. W. e NÓVOA, A. (orgs). Porto - Portugal - Porto Editora: 1998.

ZITKOSKI, J. J. Paulo Freire \& a educação. Belo Horizonte: Autêntica, 2006.

Recebido em 06 de agosto de 2020.

Aprovado em 20 de janeiro de 2021.

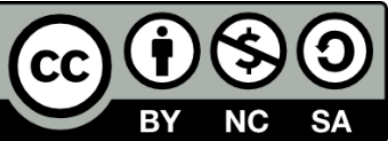

